\title{
P. C. Geissler
}

\section{CASPAR HAUSER'S ERMORDUNG (1833/34)}

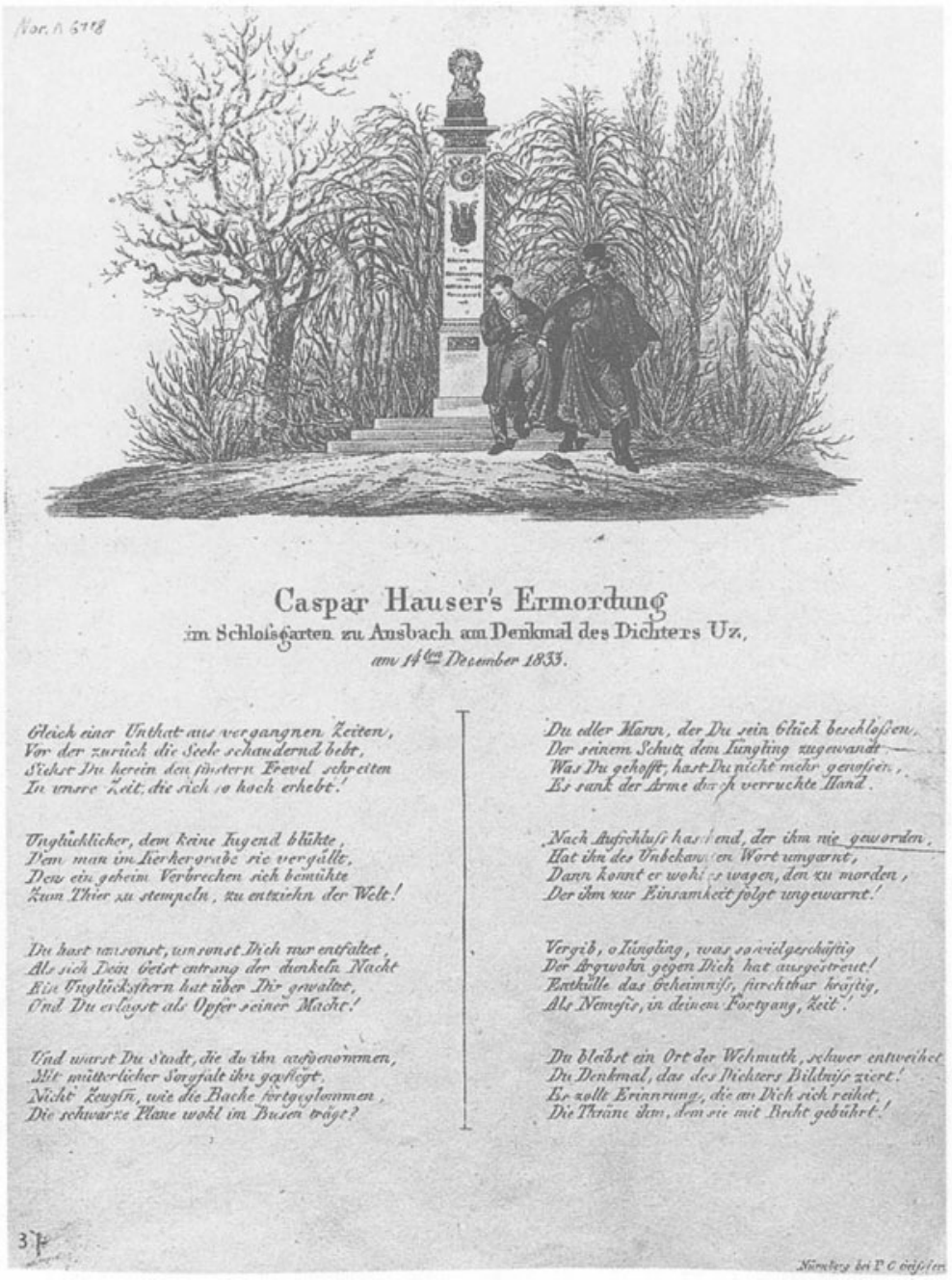

32

U. Struve (Hrsg.), Der Findling Kaspar Hauser in der Literatur

(C) Springer-Verlag GmbH Deutschland 1992 